\title{
Is the Carboniferous $\uparrow$ Adiphlebia lacoana really the "oldest beetle"? Critical reassessment and description of a new Permian beetle family
}

\author{
JARMILA KUKALOVÁ-PECK ${ }^{1}$ and Rolf G. BEUTEL ${ }^{2}$
}

\author{
${ }^{1}$ Department of Biology, Carleton University, Ottawa, Ontario, K1S 5B6, Canada; e-mail: jarmila_peck@carleton.ca \\ ${ }^{2}$ Entomology Group, Institut für Spezielle Zoologie und Evolutionsbiologie mit Phyletischem Museum, FSU Jena, Erbertstrasse 1, \\ 07743 Jena, Germany; e-mail: rolf.beutel@uni-jena.de
}

Key words. Oldest beetle, Coleoptera, $\uparrow$ Adiphlebia, $\uparrow$ Strephocladidae, $\uparrow$ Tococladidae, fossils, Neoptera, $\uparrow$ Moravocoleidae fam. $\mathrm{n}$.

\begin{abstract}
Béthoux recently identified the species $\uparrow$ Adiphlebia lacoana Scudder from the Carboniferous of Mazon Creek, Ill., USA as the oldest beetle. The fossils bear coriaceous tegmina with pseudo-veins allegedly aligned with "rows of cells" as they occur in Permian beetles and extant Archostemata. The examination of four new specimens of $\uparrow$ Adiphlebia lacoana from the same locality revealed that the "cells" are in fact clumps of clay inside a delicate meshwork, and no derived features shared with Coleoptera or Coleopterida (= Coleoptera + Strepsiptera) were found. Instead, †Adiphlebia lacoana bears veinal fusions and braces similar to extant Neuroptera. These features support a placement in $†$ Strephocladidae, and are also similar to conditions found in $\dagger$ Tococladidae. These unplaced basal holometabolan families were erroneously re-analyzed as ancestral Mantodea and Orthoptera. Homologization of the wing pairs in neopteran lineages is updated and identification errors are corrected. A new Permian beetle family $\uparrow$ Moravocoleidae [†Protocoleoptera (= Permian Coleoptera with pointed unpaired ovipositor; e.g., †Tshekardocoleidae)] is described.
\end{abstract}

\section{INTRODUCTION}

With about 350,000 described species (Grimaldi \& Engel, 2005) Coleoptera are presently the most speciesrich insect order. It has been commonly accepted that the oldest beetles occurred in the Early Permian (e.g., Ponomarenko, 1969; Kukalová, 1969; Kukalová-Peck \& Lawrence, 1993, 2001; Beutel, 1997; Beutel et al., 2008). These extinct species were assigned to the taxon $\dagger$ Protocoleoptera (†Tshecardocoleidae, †Oboricoleidae, †Moravocoleidae fam. n.; see below), the first branch of the coleopteran stem group, i.e., the sistergroup of the remaining Coleoptera s. 1. (Beutel, 1997; Beutel et al., 2008). †Protocoleoptera are characterised by an unpaired, apically pointed ovipositor (apomorphy) and apically pointed elytra clearly projecting beyond the abdominal apex (plesiomorphy). Recently, this was challenged by Béthoux (2009), who identified three specimens of $\uparrow A d i$ phlebia lacoana Scudder, 1885 from the Late Carboniferous (Middle Mississippian, Westphalian D, of Mazon Creek, Illinois, USA) as the oldest known ancestral beetles. All these fossils bear distinctive features unknown in the fossil and extant Coleoptera: a long, posteriorly heartshaped, anteriorly narrowing prothoracic shield, oval coriaceous tegmina held in a roof-like position at rest, hind wings shorter than forewings, and a pronouncedly narrowing abdomen much shorter than the flexed wings. Béthoux (2009) assigned these specimens to Coleoptera based exclusively on one feature of inter-veinal network formed from the wing membrane: the presence of rows of angular cells parallel to the principal veins and flanking the intercalary pseudo-veins. No apomorphic features of Coleoptera are mentioned from those listed by Beutel \&
Haas (2000) or Beutel et al. (2008), and no wing organ apomorphies suggested by Kukalová-Peck \& Lawrence (2004) for Coleopterida (Coleoptera + Strepsiptera) (Wiegmann et al., 2009; Beutel et al., 2011) are present.

The purpose of the present study is to re-evaluate the ordinal interpretations of Béthoux and to bring attention to some significant wing features of Neoptera characteristic for presumably the basal endoneopteran (= holometabolan) lineages. Four additional specimens of $\dagger$ Adiphlebia lacoana from the same locality are described, compared to Béthoux' exemplar and analyzed with respect to preservation and recognizable similar features in Paleozoic and modern insect groups. Specific features of the Mazon Creek Lagerstätte and Mazon Creek fossils are evaluated. Based on the evidence presented here the assessment of $\dagger$ Adiphlebia lacoana as the earliest beetle is critically re-evaluated.

\section{MATERIAL AND METHODS}

\section{Material examined \\ Extant insects}

Coleoptera, hind wings. Archostemata: 3 families, 9 genera. Neoptera wing organ (articulation, wing base, wing venation) fully homologized, as in the taxa listed by Kukalová-Peck \& Lawrence (2004, pp. 134-135, 137-144).

Fossil insects

Order uncertain: $†$ Strephocladidae Martynov, 1938: $†$ Adiphlebia lacoana Scudder, 1895; Middle Pennsylvanian (Moscovian), Mazon Creek locality, Illinois, U.S.A, specimen \#1/2010 a b, JKP collection, Carleton University, Ottawa, Canada; specimen TVT \# 2023 a b, collection of Mr. Thomas V. Testa, Coal City, Illinois; specimen \# 14890a and \# 14886ab, Illinois State Museum, Springfield, Ill., USA. †Spargoptilon confertus 

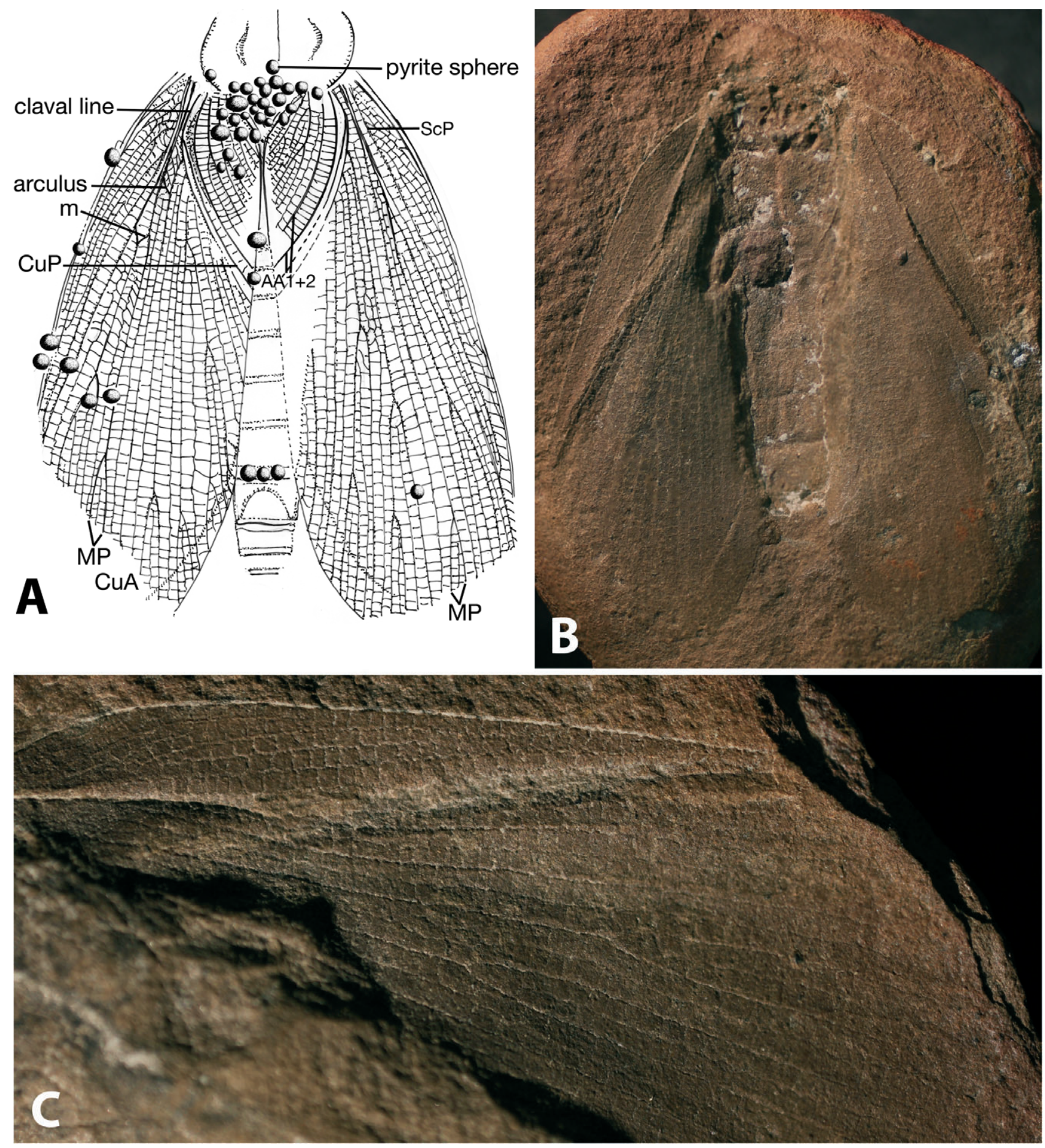

Fig. 1. †Adiphlebia lacoana Scudder, 1885, Piecko specimen 1/2011 a, b, collection of J. Kukalová-Peck, Ottawa, Canada. Well preserved specimen requiring no preparation. Length of wing remnants: $20 \mathrm{~mm}$. A - Composite drawing of both halves combined. Arculus (mp-cua cross-vein) and medio-medial brace $(\mathrm{m})$ are distinct only in the left wing. Wing flexing is roof-like. Wing braces, fluting, branching, folds, lines, etc. similar to Neuropterida + Mecopterida. B - Imprint shows aggregates of pyrite growing naturally into above-fossil space (they are not denuded by preparation). C - Left wing showing delicate meshwork, thin veins and pseudoveins. Mesh openings may attract paper-thin clumps of clay, which should appropriately be scratched away with needles. Béthoux (2009) mistook these artefacts for pits in beetle elytra, and classified †Adiphlebia erroneously as the oldest beetle. Figure by Kukalová-Peck, photographs by J. Prokop.

Kukalová, 1965; Early Permian, Obora, Czech Republic. $\uparrow$ Homocladus grandis Carpenter, 1966; †Paracladus retardatus Carpenter, 1966, Early Permian, Elmo, Kansas. Order uncertain. $\dagger$ Tococladidae Carpenter, 1966: †Tococladus rallus Carpenter, 1966, Early Permian Elmo, Kansas; †Tococladus garrici
Béthoux et al. 2003, Saxonian Group, Salagou Formation, Herault. France; †Tococladus similis Novokshonov, 1999. Coleoptera s. 1. (i.e. including entire stem group): †Protocoleoptera: †Moravocoleidae, fam. n., †Moravocoelus permianus Kukalová, 1969, Early Permian (Artinskian), Obora, Czech 




Fig. 2. †Adiphlebia lacoana Scudder, 1885, Testa specimen TVT 2023, collection of Mr. Thomas V. Testa, Coal City, Illinois, USA. Tegmen, maximum length $18 \mathrm{~mm}$; shield length 9.3 $\mathrm{mm}$. Shield is relatively very large, covered by cuticular archedictyon. Field cua-cup is very narrow, as also in specimen \# 14886. Hind wing venation is imprinted through tegmina so that arculus and medio-medial brace $(\mathrm{m})$ are unrecognizable. Very slight overlap is consistent with the roof-like position of wings at rest. Figure by Kukalová-Peck.

Republic. †Ademosynidae Ponomarenko 1968: †Ademosyne speciosa Riek, 1974, Late Triassic, Republic of South Africa.

\section{Techniques}

Living insects

We used binocular dissecting microscopes with magnifications up to $150 \times$. The wing organ was examined in three integrated wing character complexes: the articulation, the wing base braces, and the venation including flexion lines and folds. Fully homologized all-pterygote wing nomenclature unified and tested in all modern and fossil orders was employed (Kukalová-Peck \& Lawrence, 2004; Kukalová-Peck, 2008, 2009). The best preparation is the dry mount. The darkest, most sclerotized insect specimens were boiled or placed in potassium hydroxide for a brief period only, and then the wings were stretched to the sides and away from the body, secured, and left to dry. The specimen was then placed on a pin, mounted on a small handheld object and the wings turned in all directions so as not to miss features hidden to dorsal view. The wing base was exam-

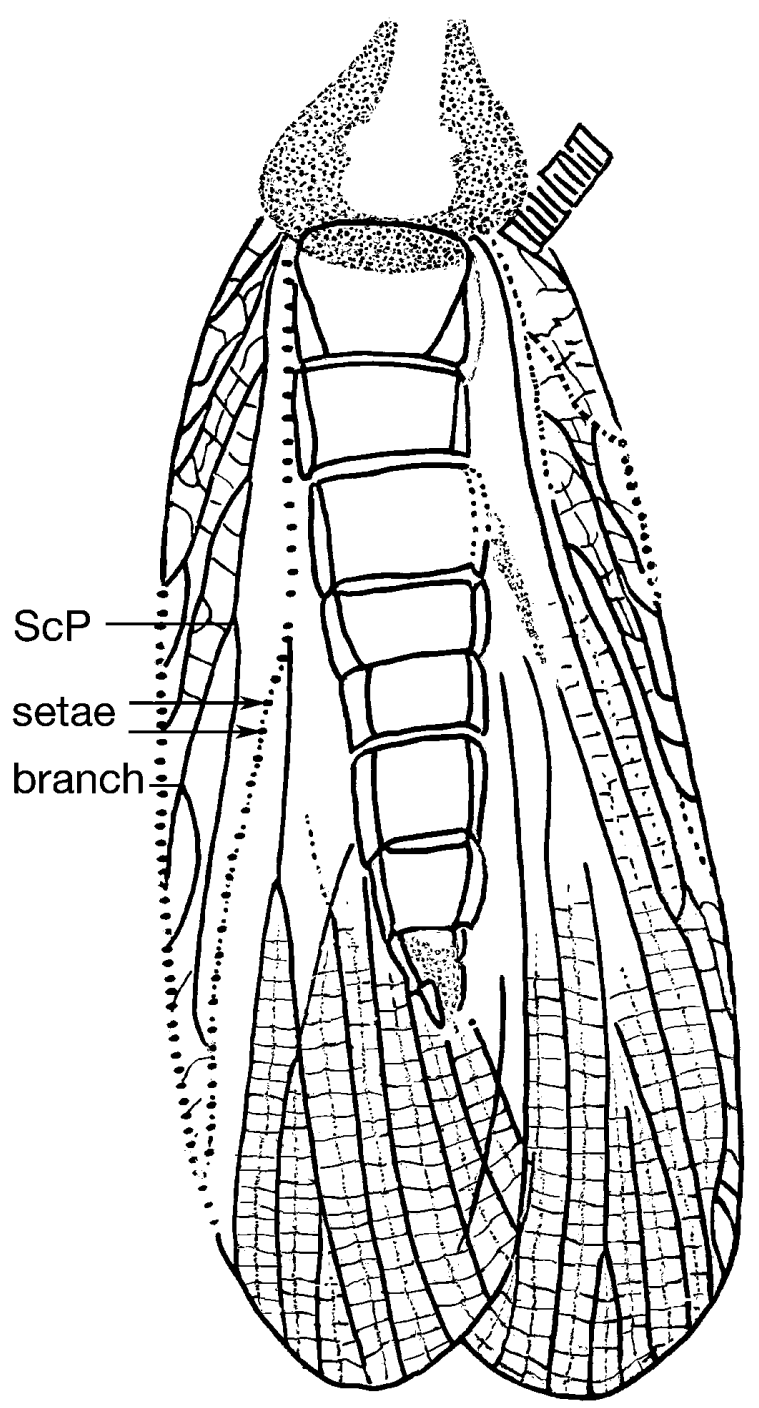

Fig. 3. †Adiphlebia lacoana Scudder, 1885. Specimen \# 14886 a, Illinois State Museum, Springfield. Tegmen, total length $15 \mathrm{~mm}$. A badly preserved specimen shows large bases of macrotrichia on the veins. Abdomen is slimmer and shorter than in all other specimens. Figure by Kukalová-Peck.

ined three-dimensionally but drawn in detail in two planes only and shaded, to show the shape and superposition of veins and sclerites, which would be hidden by overlap in natural imaging. The wings were then flipped and the wing base crosschecked on the ventral side to verify the mutual position of veinal sectors at the immediate wing base. The starting points of veinal sectors $\mathrm{MA}+$ and MP- from the medial basivenale are often completely hidden under the radial vein and visible only after the wing base is strongly tilted, flipped, or even sectioned. Membranized connections between veins and their basivenalia may stand out only after staining. Weakly expressed details were verified in several specimens, and only the best preserved ones were drawn.

\section{Fossil insects}

Fossils were studied by binocular dissecting microscope with a low-angle light from only one side. They were hand-held and slowly rocked and turned to show the best relief. Most figures were redrawn from enlarged photographs crosschecked against the original, and minor details were added by hand. The figure of the imprint was redrawn on transparent paper, flipped, examined against the counter-imprint, and all missing or differently 

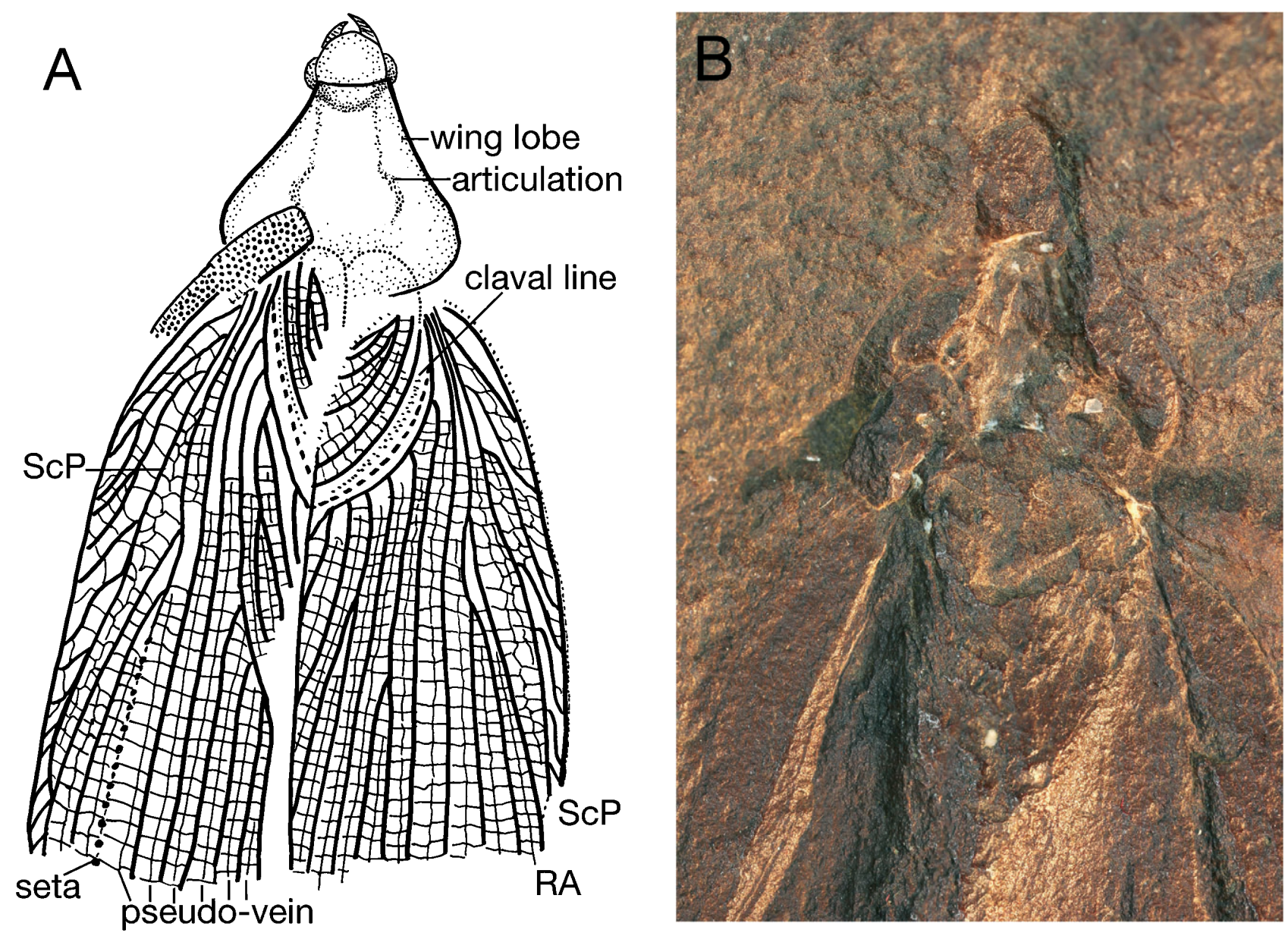

Fig. 4. † Adiphlebia lacoana Scudder, 1885. Specimen \# 14890 ab, Illinois State Museum, Springfield. Shield length $5.3 \mathrm{~mm}$; wing fragment length $20 \mathrm{~mm}$. A - Original drawing of both halves, combined. Prognathous head appears small for the specimen size. Shield is relatively smaller than in the Testa specimen. Arculus and m-brace are indistinguishable. Wings flexed in a roof-like position, as in Neuroptera. B - Same specimen \# 14890, cleaned by preparation. Specimen was covered by patches of white kaolinite and paper-thin clumps of clay creating false "elytral cells" as in the false beetle elytra of Béthoux (2009). Needle preparation and brushing leave behind sheen and fine scratches, but natural structures are unchanged. Figure by Kukalová Peck, photograph by J. Prokop.

preserved features were added or corrected in red pencil, rechecked and updated repeatedly from both sides. The figures combine the characters of the obverse and reverse imprint (as is customary), but only one of these two imprints is pictured in a photograph (= some parts present in a figure may be naturally missing in a photograph).

\section{RESULTS}

\section{New specimens of $\uparrow$ Adiphlebia lacoana Scudder, 1885}

All four specimens share the characteristic oval tegmina; rich, long, densely arranged, neutrally fluted branches of RP, MA, MP, CuA running closely and in parallel; $\mathrm{CuP}$ weak and followed by a shortened claval line; macro- and microtrichia; and especially the typical, broad subcostal area with long, forked, steeply slanted ScP braches. Veinal braces mp-cua and $\mathrm{m}$, preserved only in our specimens (Fig. 1A), were newly added. All these veinal features are characteristic for $\uparrow$ Strephocladidae (Figs 5,6) and support a placement in this family. The pattern and braces of main veins are also similar to †Tococladidae (Fig. 7). Antennae and genitalia are missing in all known specimens. The legs were appar- ently strongly developed but are preserved only as small fragments.

Piecko specimen \# 1/2011 a, b (Fig. 1A, B, C) (collected by Ms. Helen Piecko, Chicago, USA; collection of J. Kukalová-Peck, Carleton University, Ottawa, Canada. Dimensions: right tegmen maximum length $20 \mathrm{~mm}$, maximum width $8 \mathrm{~mm}$. This specimen has a beautifully preserved wing surface free from clay deposits, so that no preparation was necessary.

Description: The wing shows reduced ScA and nearly regular fine cross veins forming unusually long pseudoveins (= intercalated sectors). All meshwork is delicate and no "cells" are present. In the left tegmen, the Piecko specimen offers a very important contribution to the genus $\uparrow$ Adiphlebia, namely two significant medial braces. These are: an obliquely slanted flight-important mp-cua brace supported by several equally slanted elements from the meshwork (Fig. 1) shared by Endoneoptera and Hemineoptera [= Acercaria, Paraneoptera (excl. Zoraptera)], and a medio-medial brace m (ma-mp cross-vein brace/short fusion) typical for modern Neuroptera, and 


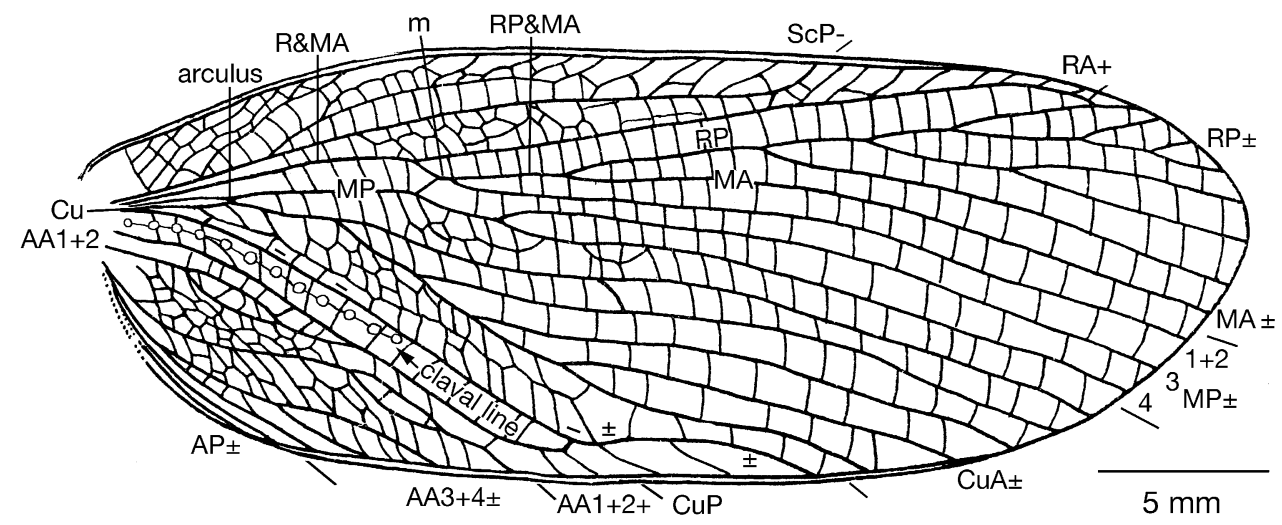

Fig. 5. †Strephocladidae: †Spargoptilon confertus Kukalová, 1965, fore wing, holotype. Early Permian (Artinskien), Obora, Czech Republic. After Kukalová 1965, Fig. 16, and Pl. 8/1, symbols updated.
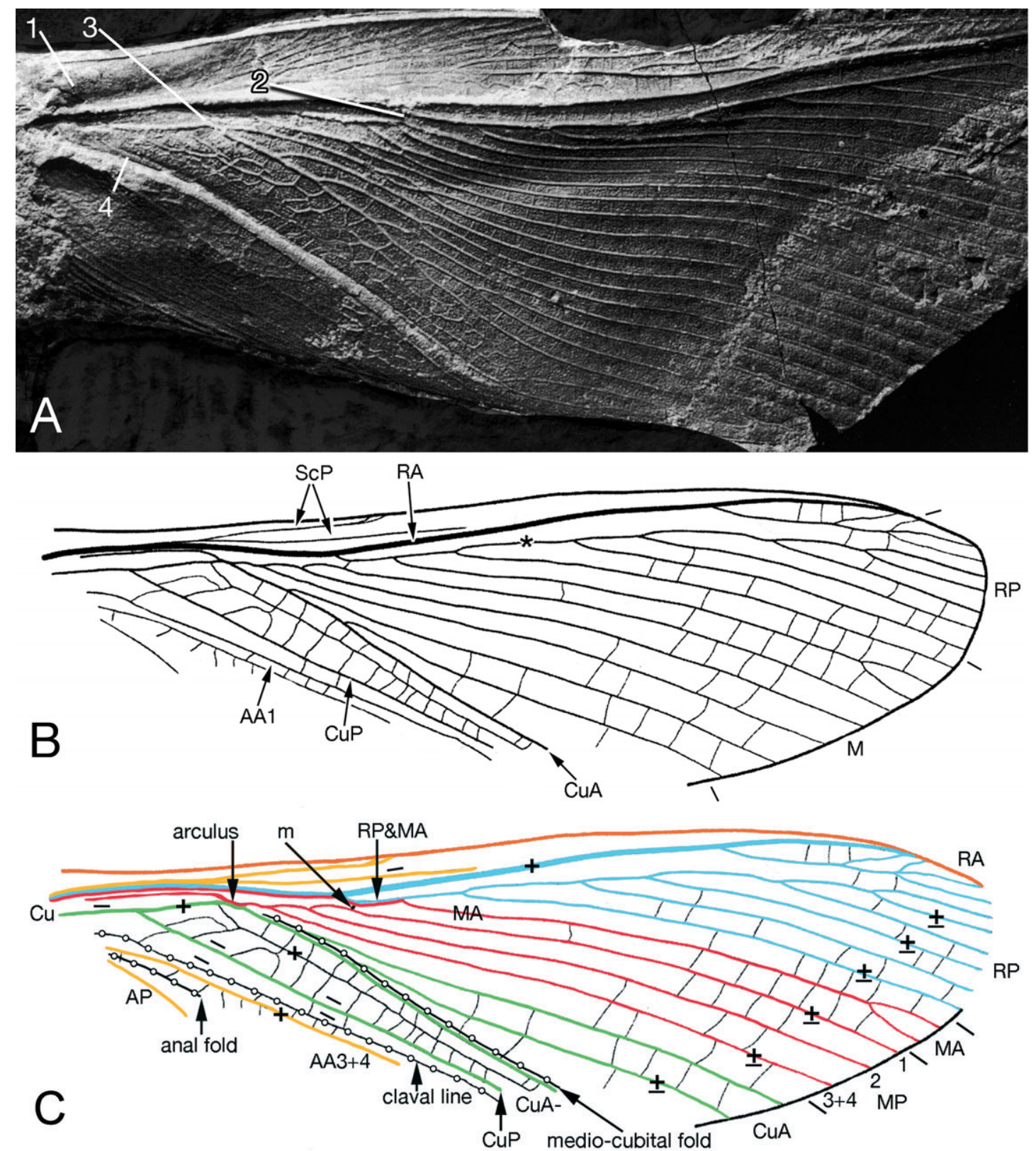

Fig. 6. †Strephocladidae: $\uparrow$ Homocladus grandis Carpenter, 1966, Late Carboniferous, Mazon Creek, Illinois. A - Fore wing, holotype. 1 - subcostal bulge; 2 - $\mathrm{m}$ brace formed by a cross-vein; 3 - flight-important mp-cua brace/fusion shared by Endoneoptera + Hemineoptera; 4 - claval line short, concave. B - †Homocladus cf. grandis, hind wing, Béthoux et al., 2010, Fig. 4. C - Same, venation and flexion lines verified by us with a photograph, fully homologized and identified by unified nomenclature as endoneopteran. 

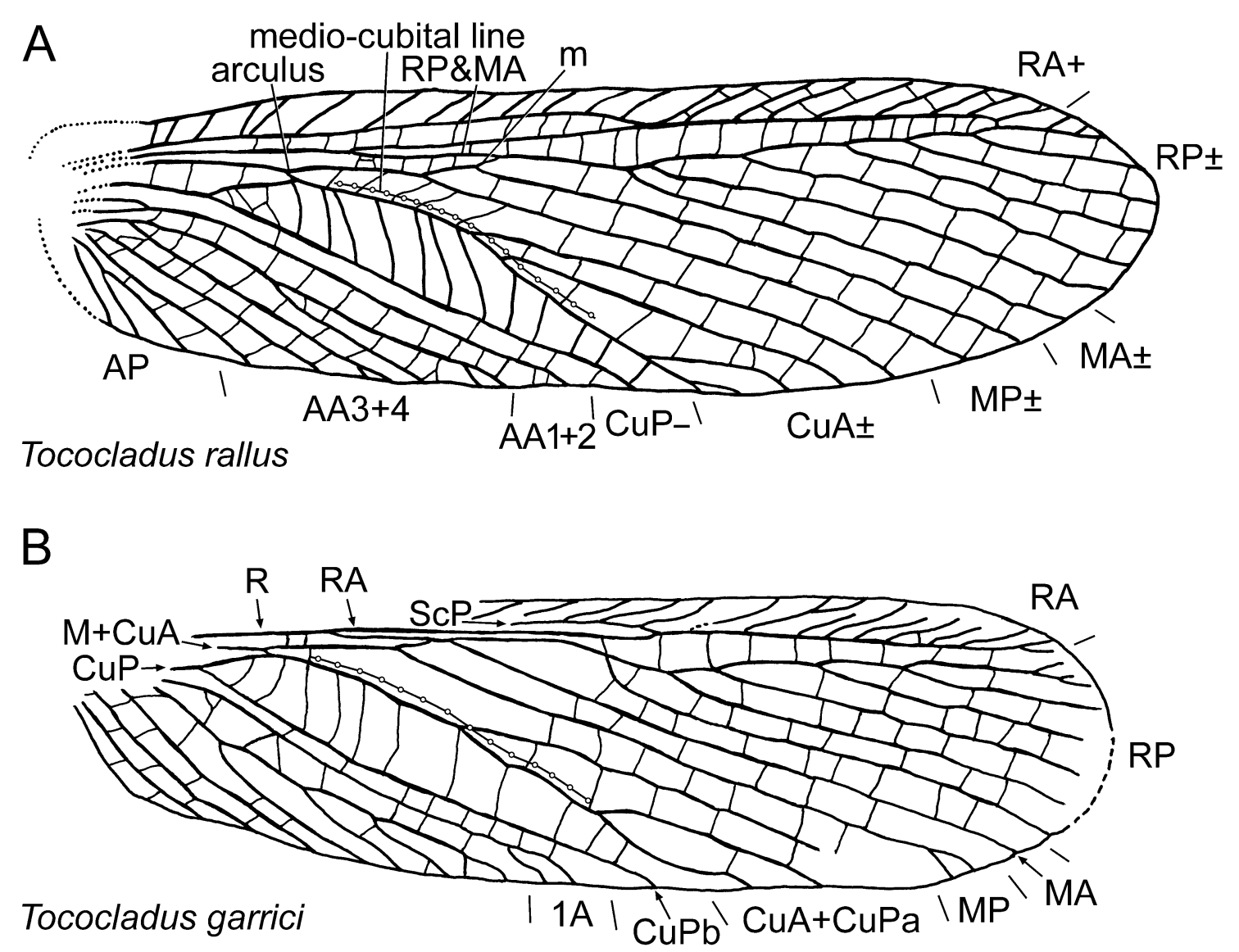

Fig. 7. Unplaced Permian endoneopteran family †Tococladidae. A - †Tococladus rallus Carpenter, 1966, fore wing, holotype, Early Permian of Kansas. Fully homologized venation with unified nomenclature shows similarity to $\uparrow$ Strephocladidae (Figs $5 \mathrm{~A}$ and 6 , here). B - †Tococladus garrici Bethoux, 2003, fore wing, holotype. Permian, Herault, France. Veinal pattern shows misinterpreted "M+CuA fusion" unique for orthopteroids. Cubital veins were given unique symbols $\mathrm{CuPa}$ and $\mathrm{CuPb}$ not used in other lineages (Béthoux, 2003). Veinal pattern and medio-cubital line are close to †Strephocladidae, Neuroptera and Mecoptera. A - figure from holotype with nomenclature by Kukalová-Peck; B - after Béthoux et al. (2003, Fig. 3).

often repeated several times $(\mathrm{m} 1, \mathrm{~m} 2, \mathrm{~m} 3, \mathrm{~m} 4)$. Strong veinal corrugation occurs in veins $\mathrm{ScP}-, \mathrm{R}+, \mathrm{RA}+$, while veins $\mathrm{RP} \pm, \mathrm{MA} \pm, \mathrm{MP} \pm, \mathrm{CuA} \pm$ are neutral [leveled $( \pm)]$ as characteristic for Endoneoptera (= Holometabola). CuA branches are directed anteriorly (as in $\uparrow$ Strephocladidae, Figs 5-7). CuP- is slightly concave and distally weakened. The claval line is mildly concave and shortened. First anal vein $(\mathrm{AA} 1+2)$ is vertically elevated, and the remaining anal veins $(\mathrm{AA} 3+4, \mathrm{AP})$ are neutral to convex.

Veinal differences: In $\dagger$ Adiphlebia lacoana, the area between $\mathrm{CuA}$ and $\mathrm{CuP}$ is narrow, as in some Mecoptera, and much narrower than in other $\dagger$ Strephocladidae (Figs 5, 6), $\dagger$ Tococladidae (Fig. 7) and in Neuroptera (possibly an autapomorphy at the $\dagger$ Adiphlebia level). In the anal area of Piecko specimen \# 1/2010 has (Fig. 1A, right fore wing), AA1+2 bears two strongly convex branches AA1 and $\mathrm{AA} 2$, while $\mathrm{AA} 3+4$ and $\mathrm{AP}$ are dichotomously branched and running in parallel (a plesiomorphy). In contrast, the anal veins in other $\dagger$ Strephocladidae ( $\dagger$ Spargoptilon: Fig. 5, and $\dagger$ Homocladus: Fig. 6$)$ tend to form small anal loops (present in many blattoids, hemipteroids, $\dagger$ Protomecoptera, $\uparrow$ Miomoptera, and in modern Mecopterida).

Pseudo-veins: Even though $\uparrow$ Strephocladidae occasionally bear short pseudo-veins, those in †Adiphlebia lacoana are by far longer, more numerous and more regular, and almost equally strong as the principal veins (a presumptive autapomorphy of the genus). All pseudoveins remain less straight and not quite at the same level as true veins and branches. The cross-veins supporting pseudo-veins are dense, fine, almost straight, and mostly almost regular, except in the subcostal area. They are strongly dissimilar to the type of pseudo-veins and crossveins occurring in the oldest fossil Coleoptera (Fig. 8).

Macrotrichia and microtrichia. All veins and crossveins are densely covered by rows of large macrotrichia (as in many Endoneoptera, especially in Neuroptera and Mecopterida). The wing membrane bears dense microtrichia as in some Blattoneoptera* and in many Endoneoptera.

Pyrite globules: Specimen \# 1/2010 (Figs 1A, B) has a natural crisply preserved wing surface free of clay min-

\footnotetext{
* The terms Blattoneoptera [Dictyoptera, Grylloblattodea, Dermaptera, Zoraptera (?)], Orthoneoptera (Phasmatodea, Orthoptera) and Pleconeoptera (Plecoptera, Embioptera) reflect a phylogenetic concept of the first author (JKP).
} 

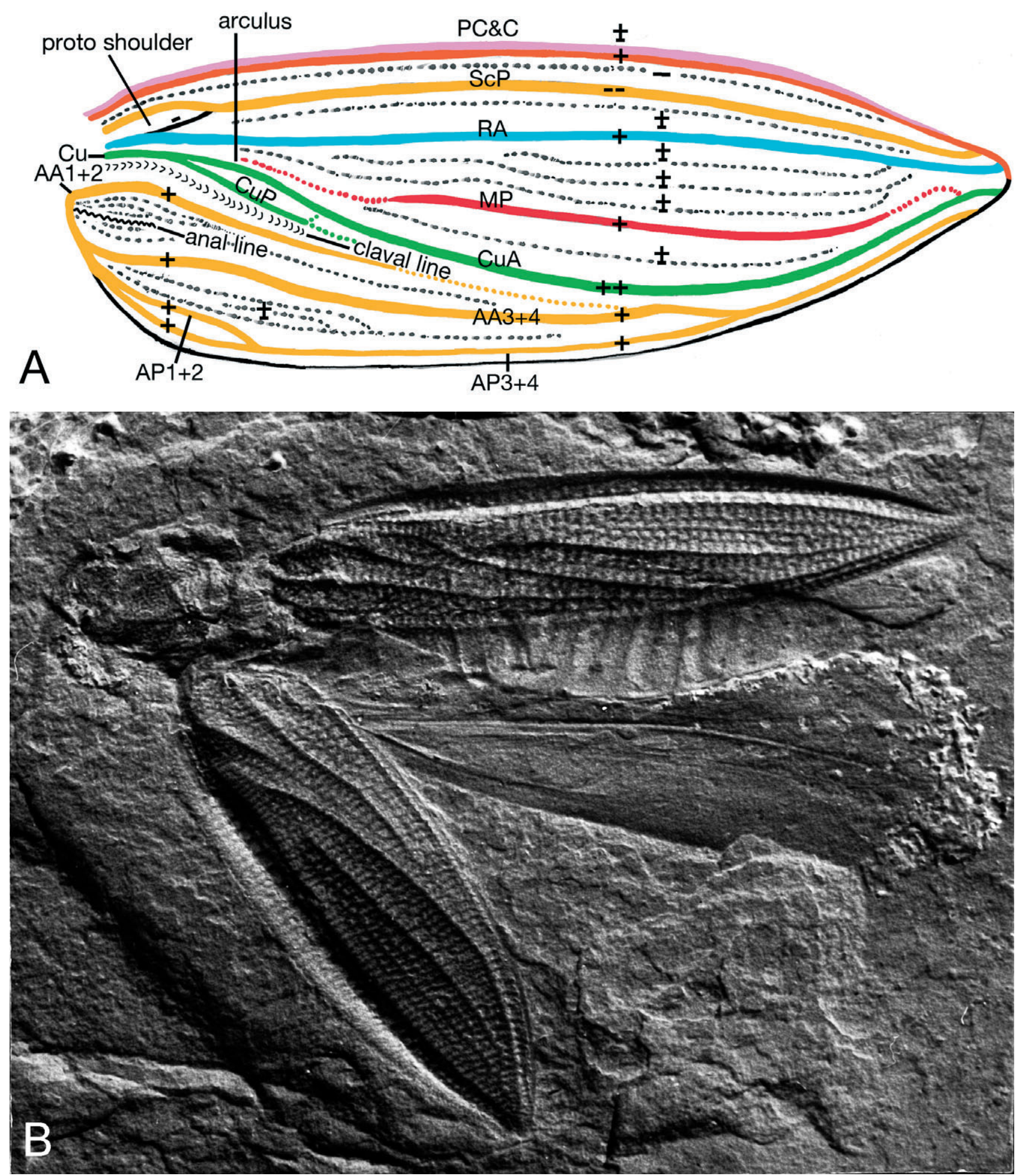

Fig. 8. †Protocoleoptera: †Moravocoleidae fam. n.: †Moravocoleus permianus Kukalová, 1969, holotype, Early Permian (Artinskian), Obora, Czech Republic. A - Holotype, left elytron. B - Holotype distorted by tectonic pressure. Elytra are sclerotized, convex, with locking posterior margins ending flush with the end of the abdominal outer ovipositor. Hind wing longer than elytron, of blattoid type with a greatly enlarged AP lobe. A - Figure by Kukalová-Peck; B - after Kukalová-Peck \& Lawrence, 1993.

erals (no preparation was needed), covered in places by little globules of pyrite naturally protruding into the space above (Fig. 2A, B). As shown in our figures, pyritic micro-aggregates grow freely from insect bodies and are much softer than the matrix of the "ironstone" nodules (Baird, 1997). Therefore, they cannot and do not provide the "ultimate proof" that the matrix around them was removed to depth around insect structures by "excessive preparation" as charged by Béthoux \& Briggs (2008).

Testa specimen \# TVT 2023 (Fig. 2); collection of Mr. Thomas V. Testa, Coal City, Illinois: Prothoracic shield length $9.3 \mathrm{~mm}$; tegmen, maximum length $18 \mathrm{~mm}$, width 


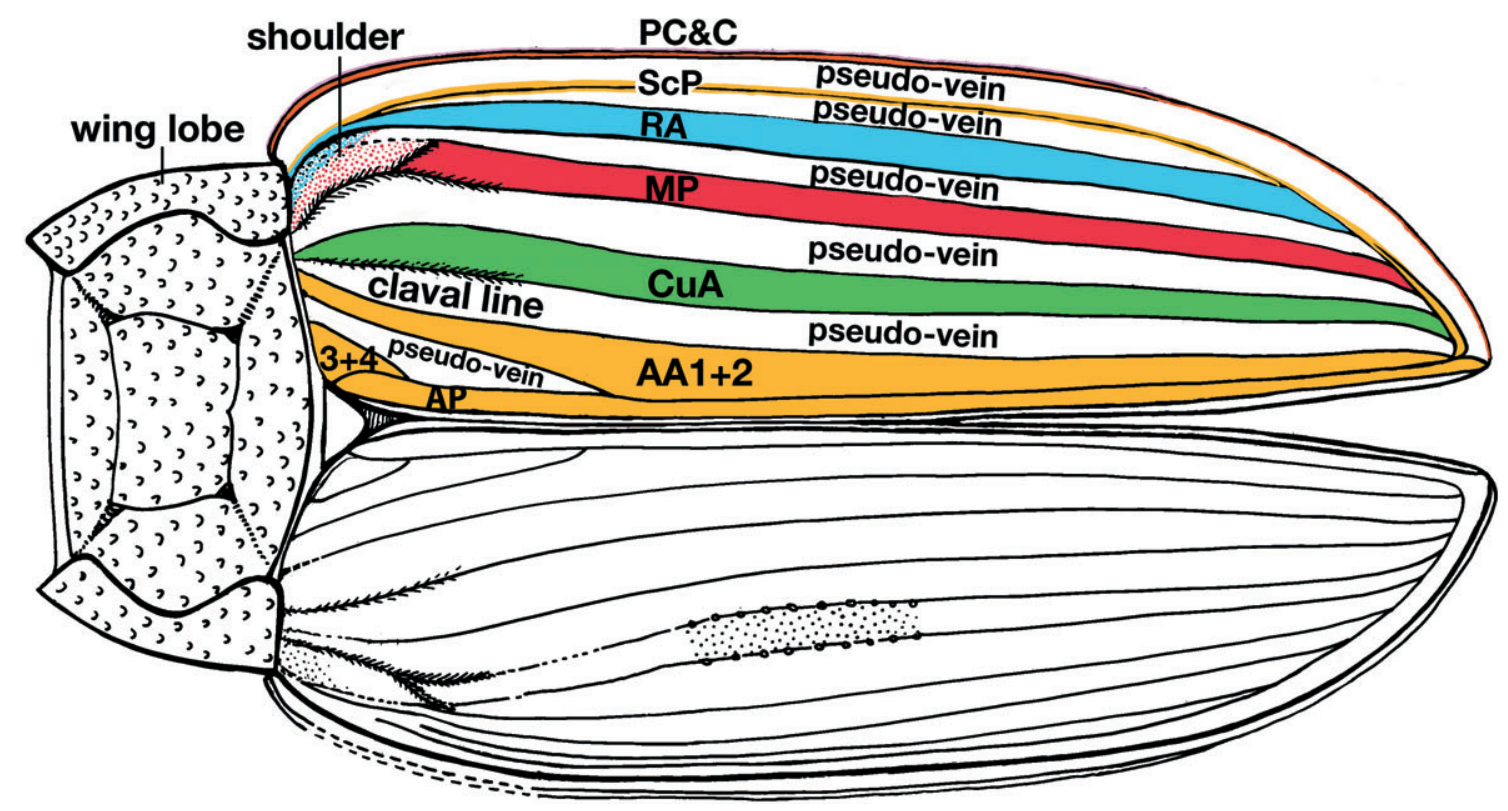

Fig. 9. Coleoptera: †Ademosynidae: †Ademosyne speciosa Riek, 1974, Middle Triassic, South Africa. Prothoracic shield with wing-shaped lobes separated from protergum by sulci (shallow sutures). Shoulders narrow, placed at MP base. Veins reduced as shown. Anal veins with a long AA1+2 (as in Polyphaga), short AA3+4 and a long AP.

$8.5 \mathrm{~mm}$. Prothoracic shield with surface covered by dense cuticular archedictyon on both protergum and fused winglets. Forewing anal area shows plesiomorphic parallel veins and pseudo-veins, as in Piecko specimen. Weak, concave CuP is closely followed by an equally weak and concave but much shorter claval line. Veinal system is similar as in the Illinois State Museum specimens and Piecko specimen \# 1/2010. But, ScP- branches in the Testa specimen and State Museum specimens is somewhat shorter, less dense and less parallel than in the Piecko specimen, and more similar to $\uparrow$ Strephocladidae from other localities.

Illinois State Museum specimen \# 14886a (Fig. 3), Illinois State Museum, Springfield: Wing length $15 \mathrm{~mm}$. This specimen shows 5 segments of a narrow, pronouncedly tapering abdomen, dissimilar from all abdomens known in the Paleozoic and modern Coleopterida. Clay deposits on this specimen were removed by needles and brushes.

Illinois State Museum specimen \# 14890 (Fig. 4), Illinois State Museum, Springfield: Shield length $5.3 \mathrm{~mm}$, width $6.2 \mathrm{~mm}$; head length $2.5 \mathrm{~mm}$; wing fragment length $20 \mathrm{~mm}$, maximum width $9 \mathrm{~mm}$. Clay deposits on this specimen were removed by needles and brushes.

\section{Unusual preservation of insects in Mazon Creek nodules}

Mazon Creek insects are three-dimensionally preserved in very hard siderite "ironstone" nodules, formed by ions attracted to the decaying remnants of animals and plants. During fossilization, insect exoskeletons were desclerotized and then often misshaped, with a space left around them in a nodule. This was often filled out by white kaolinite, butter-soft limonitic clay minerals, and by small crystals or spheres of pyrite growing directly from the fossils into space above them (Figs 1A, B) (Baird, 1997; Kukalová-Peck, 2009). The nodules often split partly above and partly inside the insect body so that the obverse and reverse imprints do not match. Two kinds of specimen preparation are appropriately used. The legs, heads, mouthparts, genitalia, and large spines entombed deep in the hard matrix are routed out by a heavy-duty vibrating engraver. In contrast, the soft paper-thin clay layer coating fossils within the space inside the nodule alters fine details, and thus is appropriately scratched away manually with needles (ultrasound cleaning destroys fossils) (Kukalová-Peck, 2009). The preparation method was established by E.S. Richardson, the founder of the Mazon Creek fossil collection and curator of paleontology at the Field Museum of Natural History, Chicago, Illinois.

The same thin layer which should be appropriately removed created the false "beetle elytra" effect, an apparent artefact described by Béthoux (2009) as the "rows of cells" (see below). The clay is inseparably fused to the black carbonized powdered layer on top of the insect cuticle, which is usually more or less brushed off. Needle scratches remain visible, and the surface often has a false "polished" look and sheen from repeated brushing away the fine debris. Under alcohol, the cleaned specimen looks "naked," scratched, and is covered by protruding pyrite. But, since the natural surface is firmer than the clay, the actual fossil suffers mostly minor damage. As erroneously stated by Béthoux \& Briggs (2008), the removal of clay deposits by Kukalová-Peck created in Mazon Creek fossils the supposedly non-existing outer limb rami (= exites), which were then used as the evidence for a "major theory of wing origin". This was hardly necessary: much better preserved exites were also described from three other Paleozoic localities, exites and 
endites occur in arthropods from the Cambrian to modern times, and some exites (e.g., abdominal plate "gills", coxal styli) and many endites (e.g. maxillary and labial endite lobes, gonostyli, penes, ovipositor valves) are present in modern insects! (Kukalová-Peck, 2008, Figs 1, 3, $4,9,10,12)$.

\section{DISCUSSION}

\section{The non-beetle $\uparrow$ Adiphlebia lacoana Scudder, 1885}

About $95 \%$ of all Palaeozoic insects are known only from the fore wings. The problem with assessing the systematic position of $\uparrow$ Adiphlebia lacoana is the scarcity of interpretable characters besides the fore wings. The very few recognizable morphological features do definitely not allow a formal cladistic character evaluation. There is absolutely no information on the ventral side, pleural parts, legs, and male and female genitalia. The head is missing in most specimens and if it is present [in one of three specimens examined by Béthoux (2009), and in one of three specimens examined by us] no details [e.g., sutures, number of antennomeres, mouthparts (except for distal mandibular parts in one specimen)] are recognizable.

\section{Prothoracic shield}

The elongated prothoracic shield is anteriorly narrowed and posteriorly heart-shaped, and it bears prothoracic winglets with arched articular ridges fully fused to the protergum and separated from it only by shallow sutures. In Neoptera, partially free prothoracic winglets were retained only in some Paleozoic Pleconeoptera (Carpenter, 1992, Fig. 65/5) and movably articulated winglets were never found. Plesiomorphic wing lobes are mostly transformed into continuous protective shields and defined only by sutures, which later are more or less diminished or lost. Note that ancestral Palaeoptera (Carboniferous odonatoids and $†$ Palaeodictyoptera) bore winglets with a protowing veinal pattern, fused to the protergum by the same arched articulation as is found in $\uparrow$ Adiphlebia lacoana and in modern Neoptera (Kukalová-Peck \& Lawrence, 2004: Fig. 1; Kukalová-Peck, 2008: Fig. 16). Elongated prothoraces occur in Blattoneoptera (Mantodea) and rarely in Endoneoptera [Neuroptera: e.g., Mantispidae; Raphidioptera; few represenatives of Coleoptera (e.g., the North American cave carabid Rhadine)]. Vestiges of articular ridges are known in Blattodea, Mantodea, Zoraptera (Friedrich \& Beutel, 2008: Figs 3A, C) and Endoneoptera. In some neuropterans (e.g., Psychopsidae, Mantispidae) side lobes derived from prothoracic winglets are bent under the prothorax and either remain free or are fused ventrally along their margins. In some fossil beetles (e.g., in †Ademosynidae: Fig. 9) wingletlike structures retaining the original wing shape are reduced to narrow rims, but the curved articulation no longer forms a protruding ridge.

\section{Heart-shaped shield as a feeding adaptation}

$\uparrow$ Adiphlebia-like, elongated and anteriorly narrowed prothoracic shields combined with small heads and extra strong legs are also found in other Mazon Creek insects, with possible blattoid or holometabolous affinities (some of them undescribed), and exceptionally also in ancestral orthopteroids (Carpenter, 1992, Figs 60, 72). This peculiar adaptation probably served to reach ovules and seeds deeply imbedded into the plentiful open cone-like fructifications of pre-angiosperm plants (Shear \& KukalováPeck, 1990). The same abundant source of nourishment probably triggered the evolution of complex sucking mouthparts in basal hemipteroids, and the elongation of all mouthparts into the pronounced rostrum in $\uparrow$ Rostropaleoptera (Wootton \& Kukalová-Peck, 2000). It can be said that most of the known Carboniferous pterygotes were in some ways adapted to extricate or tap the ovules and seeds hidden in the open fructifications, and represented a much higher percentage than in the modern entomofauna. We consider the anteriorly narrowed shield, small head and strong legs (known only from fragments, Figs 3,4$)$ as an autapomorphy, either of the genus $\uparrow A d i$ phlebia, or (depending on future evidence) of the entire family $†$ Strephocladidae. Due to the rather frequent and scattered occurrence of prothoracic shields in Paleozoic fossils, which is mentioned as a diagnostic character by Béthoux (2009), this is hardly a valid argument for phylogenetic affinities of a taxon to a particular order.

\section{Meso- and metanotum}

What is visible of the meso- and metanotum (Béthoux, 2009: Fig. 2) also does not allow far-reaching phylogenetic conclusions. However, Béthoux' illustration (Béthoux, 2009: Fig. 2) strongly suggests that autapomorphic features of Coleoptera s. 1. (Beutel \& Haas, 2000; Beutel et al., 2008; Friedrich et al., 2009) are absent, namely the elevated scutellar shield and the metathoracic alacristae, both forming elytral locking devices. In a recent comprehensive evaluation of 356 larval and adult morphological characters (Beutel et al., 2011) Coleoptera were placed as the sister-taxon of Strepsiptera (= Coleopterida), just as in the wing analysis by Kukalová-Peck \& Lawrence (2004) and Kukalová-Peck (2008), and also as in a study based on six single copy nuclear genes (Wiegmann et al., 2009). In the morphology based analyses (MP, Bayesian), the characters related to posteromotorism were identified as autapomorphies of Coleopterida, among them a mesothorax (and notum) decreased in size (in relation to the pro- and metathorax) and a distinctly enlarged metathorax. This is apparently not the case in $\dagger$ Adiphlebia lacoana, which is clearly in contrast with its interpretation "as a beetle" (Béthoux, 2009).

\section{Inter-veinal network}

The placement of $\dagger$ Adiphlebia lacoana as a beetle, as suggested by Béthoux (2009), is based on a single forewing character state: "areas between ScP, RA, (branches of) RP, M, branches of $\mathrm{CuA}$, and AA filled with a regular network of quadrangular to pentagonal cells forming intercalary longitudinal pseudo-veins". It is hazardous in principle to assess the systematic position of a taxon based on a single feature (without any formal character state polarity assessment and phylogenetic analysis) and in this specific case the presumptive apo- 
morphy appeared questionable, considering the age of the fossil and other morphological evidence (equally sized pterothoracic segments, see above). Consequently a critical re-evaluation seemed appropriate.

Inter-veinal structures rising from the wing membrane are known to be present in some Permian $\dagger$ Protocoleoptera (Fig. 8) and in fossil and modern archostematan beetles (e.g., Ponomarenko, 1969; Kukalová-Peck, 1991; Beutel et al., 2008). However, the broad subcosto-radial field in Bethoux' specimens (and in some $†$ Strephocladidae: Fig. 5) appears much narrower in our specimens: Figs 1-5). Further evidence is needed to verify and evaluate this difference. In $\dagger$ Protocoleoptera (Fig. 8) this field rises abruptly from the subcostal trough, which is completely absent in $\dagger$ Adiphlebia lacoana. The interveinal network with mesh openings arranged in parallel rows and forming intercalated sectors is quite common in Neoptera. It occurs in species and genera of various lineages (see examples below) and is generally a poor indicator of phylogenetic affinities, especially when the flight-enabling fusions and braces, hind wing lobe, and the position of wings at rest are either not analyzed or largely unavailable.

\section{Position of wings at rest}

The position of the oval tegmina in $\uparrow$ Adiphlebia is distinctly roof-like as in Neuroptera and Raphidioptera, not a flat and overlapping one as in Blattoneoptera, Hymenoptera, Megaloptera, and Mecoptera, and not a flat and conjunct one as in Coleoptera.

\section{Oldest known beetles (†Protocoleoptera) and the new family $\uparrow$ Moravocoleidae}

Coleoptera, starting with the presently oldest known and accepted beetles placed in †Protocoleoptera (Fig. 8) (Kukalová-Peck, 1991; Beutel, 1997; Beutel et al., 2008), are characterised by elytra placed flat on the abdomen, meeting one another medially, locking along their posterior margin, and ending posteriorly flush with the ovipositor (in $\dagger$ Protocoleoptera).

\section{$\uparrow$ Moravocoleidae, fam. n., Kukalova-Peck \& Beutel}

The type genus †Moravocoleus Kukalová, 1969 [Early Permian (Artinskian), Obora, Czech Republic] is known from an almost complete holotype of Moravocoleus permianus Kukalová, 1969 (Fig. 8).

Genera included: $†$ Moravocoleus, $†$ Eocoleus, $†$ Umoricoleus, †Boscoleus, †Votocoleus, $\uparrow$ Prosperocoleus, and $\uparrow$ Retelytron (described by Kukalova, 1969). Veinal symbols are updated by us as in Fig. 8 .

Description: The elytra are sclerotized, convex, with locking posterior margins ending flush with the end of the exposed ovipositor. Elytral veins $\mathrm{PC} \& \mathrm{C}+, \mathrm{ScP}-, \mathrm{RA}+$, $\mathrm{MP}+, \mathrm{CuA}+, \mathrm{AP} 3+4+$ acquired coleopteran proximodistal orientation, while RP \& $\mathrm{MA} \pm, \mathrm{MP} 1+2 \pm, \mathrm{CuP} \pm$ became more or less repressed. MP is sometimes branched [instead of always single as in modern Coleoptera (plesiomorphic)]. $\mathrm{AA} 1+2, \mathrm{AA} 3+4, \mathrm{AP} 1+2$ vary in expression as in Coleoptera. $†$ Moravocoleidae fam. n. differs from the related †Oboricoleidae Kukalová, 1969 in a much narrower subcosto-radial field, the principal veins $\mathrm{MP}$ and $\mathrm{CuA}$ fully retained (both plesiomorphies), and in shorter veins $\mathrm{AA} 1+2$ and $\mathrm{AA} 3+4$ (apomorphies).

Relationship: Although $\mathrm{MP}$ and $\mathrm{CuA}$ are reduced in $\dagger$ Oboricoleidae, their fields end posterior to the apex as in $\dagger$ Moravocoleidae. The new family differs from $\dagger$ Tshekardocoleidae in the presence of a small field (protoshoulder, Fig. 8) at the base of the subcosto-radial field (apomorphy), by bearing a broad intra-anal field basally between $\mathrm{AA} 1+2$ and $\mathrm{AA} 3+4$ (apomorphy), and by retaining a remnant of $\mathrm{CuP}$ (plesiomorphy).

Protocoleopteran elytral veins are close to the basal endoneopteran pattern present in Neuroptera, Mecopterida and $\uparrow$ Strephocladidae (including $†$ Adiphlebia lacoana). They include: a shortened $\mathrm{CuP}$; shortened claval line; lost anal bar; the vertically arched bases of anal veins, mainly of AA1+2. The intra-anal field is broadly rounded, with a short anal line in the middle (as in panorpids and in Raphidioptera). Protocoleopteran apomorphies (absent in modern Coleoptera) include: small field basally between ScP and RA present; elytral shoulder placed basally on AA1+2 (instead of basally on MP \& $\mathrm{CuA})$.

\section{Preservation problems in Mazon Creek fossils and $\uparrow$ Adiphlebia}

Our own examination of four new specimens of $\uparrow A d i$ phlebia lacoana from the same Mazon Creek nodules confirmed that they are preserved three-dimensionally and differently than fossils from any other known locality (see above). Among other peculiarities, insect wings and bodies are softened, partly squashed and deformed before they fossilize, with the space between the specimen and matrix often filled with a thin layer of clay minerals tightly "glued" to the carbonized cuticular chitin. Consequently, fine outlines of sclerites, appendages, genitalia and fine veinal elements remain largely obscured, unless they are mechanically cleaned by a stiff brush and/or removed with fine needles (Kukalová-Peck, 2009). Apparently, Béthoux (2009) did not remove the thin clay layer obscuring the actual wing surface (see grains in his Figs 7, 8 and white kaolinite spots in Fig. 3) and thus the fine and somewhat irregular network-forming mesh and intercalary veins remained concealed. Instead, bulging mesh openings attracting clay debris were visible on the insufficiently cleaned surface, rather than the network around them. Béthoux (2009) considered them as the circular inter-veinal pits "typical for beetles" [i.e., the groundplan feature of Coleoptera s. 1. (Beutel et al., 2008)]. We do not accept his interpretation.

\section{The unplaced family $\uparrow$ Strephocladidae and $\uparrow$ Adiphlebia}

Our four specimens of $\uparrow$ Adiphlebia (one without preparation, three cleaned with needles and brushes) show quite distinct, slightly irregular cross-veins and pseudoveins, plus the irregular network present in most Carboniferous pterygote insects. We found the fore wing characters to be very similar to those of the family $\uparrow$ Strephocladidae Martynov, 1938. The group is known from 
isolated well preserved fore wings and a hind wing. We studied fore wings of actual specimens from the Late Carboniferous (Stephanian) of Commentry, France, the Early Permian (Artinskien) of Obora, Moravia, and the Early Permian (Autunian) of Elmo, Kansas and of Oklahoma, USA (Carpenter, 1992: Figs 73, 1, 4, 8, 9), and the rest from figures and high quality photographs. Specific features shared by $\uparrow$ Adiphlebia and $\uparrow$ Strephocladidae are the following: fore wing coriaceous, hind wings shorter than fore wing; precosto-costal strip prominent and relatively broad (a plesiomorphy in Neoptera); ScA + reduced, expressed as ScA bulge (as in Endoneoptera). ScP- shortened, ending on RA close to $2 / 3$ of the wing length (as in Blattoneoptera, Endoneoptera); ScP sending out a series of long, branched, conspicuously slanted twigs (a very unusual defining autapomorphy of this family); stem of radius present, short; branches of radius, media and cubitus very long, sinuous, parallel and neutral in fluting (a tentative synapomorphy: a similar condition occurs in modern Neuroptera and Mecoptera); MA likely fused basally to R and separating as the first branch from RP (as in Blattoneoptera and Endoneoptera, and based on indirect evidence; the alternative, MA separating from the stem of $\mathrm{M}$ occurs only in Orthoneoptera and Pleconeoptera, while associated with a very different veinal pattern: Kukalová-Peck, 2008); MP braced to RP\&MA with cross-vein/short fusion brace (m) (Figs 1, 6) (as in modern Neuropterida); MP braced to $\mathrm{CuA}$ by a short important cross-vein brace mp-cua (a fore- and hind wing synapomorphy of Endoneoptera + Hemineoptera: Haas \& Kukalová-Peck, 2001; Kukalová-Peck \& Lawrence, 2004; Kukalová-Peck, 2008) (note that a superficially similar cross-vein or fusion characteristic for Pleconeoptera and Orthoneoptera involves instead a brace or fusion between the stem of $\mathrm{M}$ and $\mathrm{CuA}$ ); stem of $\mathrm{Cu}$ very short; $\mathrm{CuA}$ branches long, apically oriented; $\mathrm{CuP}$ weakened and leveled near posterior margin; claval flexion line shortened; AA1+2 strongly elevated vertically (as in Endoneoptera); AA2+3 and AP basally fused with several parallel forks (an autapomorphy of Neoptera); network present as a mix of slightly irregular fine cross-veins and fine reticulum; pseudo-veins present; large macrotrichia present on veins (as in Neuroptera), wing membrane covered with dense microtrichia (as in many lineages of Neoptera). $†$ Adiphlebi lacoana differs from the known species of $\uparrow$ Strephocladidae in two wing characters, a $\mathrm{CuP}$ running very close to $\mathrm{CuA}$, and the presence of more and longer pseudo-veins. These wing features probably distinguish genera, but additional verification is needed.

\section{Neoptera hind wings bear two differently constructed remigia and anal lobes}

The hind wing venation in $†$ Strephocladidae is known from a single wing (Fig. 5B, C) which bears distinct higher-lever characters listed under (2), as follows: Neopteran hind wings are distinguished by two profoundly different types of remigia and anal lobes: (1) in Orthoneoptera and Pleconeoptera, the remigium starts at the concave (-) claval flexion line, and the anterior anal lobe (AA) bears $\mathrm{AA} 1+2$ branches and $\mathrm{AA} 3+4$ branches. It is followed by the anal fold and by the posterior anal lobe (AP) which bears AP1+2 branches and AP3 +4 branches (all plesiomorphies of Neoptera); (2) in Blattoneoptera, Hemineoptera, and Endoneoptera the remigium incorporates the entire anterior anal lobe $\mathrm{AA}$, in which the $\mathrm{AA} 1+2$ field and branches were reduced, and it ends at the anal fold. Consequently, the function of the anal lobe in flight is provided only by the posterior anal lobe AP with $\mathrm{AP} 1+2$ branches and AP $3+4$ branches. In blattoids, AP branches are often replenished for the function, but in hemipteroids and Endoneoptera the entire hind wings tend to hook up with the fore wings and serve as the secondary "anal lobes" (Haas \& Kukalova-Peck, 2001; Kukalova-Peck \& Lawrence, 2004). Two different compositions of Neoptera hind wings (and the extension of the remigium which promoted the flight-efficient functional dipterism) stand out only when the anal veins are fully homologized (compare Figs 5B and C). The older, faulty, but widely used empirical veinal system (Carpenter, 1992) denotes anal veins with un-homologized numbers, which masque the subdivision-level differences between anal fields.

The strephocladid hind wing shows RP, MA, MP branches as neutrally fluted, mp-cua brace and $\mathrm{m}$ brace present, medio-cubital fold pulling a portion of $\mathrm{CuA}$ into a concave position, an intercalary vein $(+)$ running between $\mathrm{CuA}$ and $\mathrm{CuP}, \mathrm{CuP}$ narrowly paralleled by a concave claval line, AA $1+2$ absent (reduced), and AA $3+4$ convex followed by the anal fold and by AP. This pattern is typical for Endoneoptera, and is more similar to the pattern found in Neuroptera, than in Mecopterida (Kukalová-Peck \& Lawrence, 2004, Figs 5, 6, 7). This relationship also coincides with the roof-like position of the folded wings in $\uparrow$ Adiphlebia. The posteriorly heartshaped and anteriorly elongated/narrowing prothoracic shield resembles the elongated shield in some neuropteran subgroups (e.g., Mantispidae, Psychopsidae). This resemblance is a parallelism, and a long prothoracic shield is not a groundplan feature of Neuroptera.

\section{$\uparrow$ Strephocladidae and Mantodea}

The wings of the unplaced basal endoneopteran family $\uparrow$ Strephocladidae were recently re-analyzed and found to be related to Mantodea (Béthoux et al., 2010). The following characters are not consistent with this conclusion. The field occupied by the RP branches is large as in Neuroptera and Mecoptera, whereas it is small in Blattoneoptera. A medio-medial brace $(\mathrm{m})$ (one or several) is present as in Neuroptera, but is absent in Blattoneoptera. $\mathrm{MP} \pm$ and $\mathrm{CuA} \pm$ is perfectly leveled as in most Endoneoptera, not slightly concave (MP-) and convex $(\mathrm{CuA}+)$ or vertically undulated as in Mantodea. A flight-important brace/short fusion mp-cua is always present in both wing pairs as in Endoneoptera, whereas it is only very rarely present in the fore wings and sometimes missing in the hind wings of Blattoneoptera. $\mathrm{CuP}-$ is weakly concave and running in parallel to a weakly concave claval flexion line as in Endoneoptera, and not running through the bottom of a deep claval line ("vena dividens") as in Blattoneoptera. AA1+2 in the fore wing is very distinct and 
strongly protruding, especially close to the base as in Endoneoptera, and not weak and irregular (or absent) as in Mantodea. The jugal area is small as in Endoneoptera, not enlarged and conspicuous as in Mantodea. In contrast, anal loops and pseudo-veins are equally frequent in Endoneoptera and Mantodea. Note that MA+ in some modern mantodeans (e.g., in Tenodera angustipennis) still retained $\mathrm{MA}+$ visibly joining $\mathrm{RP}$ at the wing base (an important synapomorphy shared by Blattoneoptera, Hemineoptera and Endoneoptera). In Blattoneoptera this fusion is usually so perfect that MA \& R look falsely like a "single" vein. Note that in Orthoneoptera and Pleconeoptera MA always fuses basally with MP into a single stem of M. These subdivision-level differences in flight adaptations present in all extinct and extant representatives (Kukalova-Peck, 1996, 2008; Haas \& KukalováPeck, 2001) were not considered by Béthoux et al. (2010). The hind wing (Figs 6B and C) has MA \pm diverging from $\mathrm{RP}$, and a concave $\mathrm{CuP}-$ followed by a parallel concave (-) claval line, with both grooves running close together as in Endoneoptera, but not merging into one claval line as in Mantodea. The veins bear prominent setae as in many Endoneoptera, but not in Mantodea. With $\dagger$ Adiphlebia added to $\dagger$ Strephocladidae, the difference from Mantodea is even more prominent. This genus shows that the wings at rest are folded rooflike as in some Endoneoptera, not flat and partly overlapping like in all Mantodea and Blattodea.

\section{Unplaced family $\uparrow$ Tococladidae and $\uparrow$ Adiphlebia}

In the Late Palaeozoic family $†$ Tococladidae, $†$ Tococladus rallus Carpenter, 1966 (Fig. 7A) and $\dagger$ Tococladus garrici Bethoux, 2003 (Fig. 7B), also have the fore wing veinal pattern similar to $\uparrow$ Strephocladidae and $\dagger$ Adiphlebia, and an unpublished specimen (currently on file with JKP) bears a heart-shaped prothoracic shield (a study in preparation by JKP). Both families share RP, MA, MP, $\mathrm{CuA}$ branches parallel and neutral, m-brace often expressed as a fusion, a short mp-cua brace, $\mathrm{CuA}$ with apically oriented branches, and $\mathrm{CuA}$ vein accompanied by an adjacent medio-cubital line (furrow) like in many Neuroptera and Mecopterida. The $\mathrm{CuA}-\mathrm{CuP}$ field is extra broad as in $†$ Strephocladidae and some Mecopterida, not narrow as in $\uparrow$ Adiphlebia. The veinal features above show the family as a basal lineage of Endoneoptera. In spite of this character set, the originally unplaced $\dagger$ Tococladidae were re-interpreted by Béthoux et al. (2003) as orthopteroids based on the following character: " $\mathrm{CuA}$ fused basally with (the stem of) $\mathrm{M}$ and separating from it only much later" (the fusion M \& CuA at the wing base occurs only in Orthoneoptera: Kukalová-Peck, 1997: Fig. 13C; Haas \& Kukalová-Peck, 2001, Fig. 15). Nevertheless, no other significant wing characters indicate the relationship to orthopteroids. We identified the "orthopteroid fusion" as an interpretation error caused by the concave mediocubital line/furrow (shown in Fig. 7A and B), which often aligns $\mathrm{CuA}$ with the brace mp-cua (arculus). When this happens, the arculus looks like $\mathrm{CuA}$ diverging from $\mathrm{M}$, while $\mathrm{CuA}$ and $\mathrm{CuP}$ actually diverge from the stem of $\mathrm{Cu}$ as clearly visible in Fig. 7A and B. The alignment is espe- cially frequent in mecopteroids including the Permian †Protomecoptera (Kukalová-Peck \& Willmann, 1990: Figs 1, 5).

\section{Which wing characters of Neoptera indicate supraordinal relationships?}

Paleozoic fossil pterygotes are mostly preserved only as fore wings without a base. However, the Neoptera wing organ bears most of the significant integrated ordinal and lineage-level characters in the fore wing base, in the hind wing anal lobe, and in the un-available wing articulation. Fossils cannot be flipped to check the veinal fusions on the ventral side, and are wide open to preservational artefacts and observation errors. These may linger uncorrected for decades. All these well known facts are on a collision course with the urgent and fundamental need for a monophyletic concept in the wing organ system and a unified nomenclature, which must cover all its integrated parts. During a long-term research program (1978-2009), the pterygote wing articulation, base, and venation were gradually re-interpreted and fully homologized by the first author based on modern insects, wing biology and arthropod anatomy, with fossils used as a significant complementary source of evidence. The results are presently published as short previews (Kukalová-Peck, 1997, 2008, 2009; Haas \& Kukalová-Peck, 2001; Kukalová-Peck \& Lawrence, 2004; Kukalová-Peck et al., 2009) but a Wing Atlas documenting significant samples from all modern orders is currently in preparation.

In a summary of the above research results, the wing venation in neopteran orders and lineages differs mainly in the following flight-related features: (i) The varied veinal supports for anterior wing margins. (ii) The medial veins MA and MP at their base are fused either with each other into the stem of M; or MA fused with RP; or M fused with CuA. (iii) The flight important cross-vein/ fusion braces m-cua, mp-cua, m (ma-mp away from base) are either present or absent. The hind wings alone differ also in the composition of the remigium. (iv) The remigium starting at the claval flexion line, with $\mathrm{AA} 1+2$ present. (v) The remigium starting at the anal fold, with AA1+2 reduced. The muscled articular sclerites generate wing movement, which is transmitted in two different routes: either via a robust body of a $2 \mathrm{Ax}$ articulated to a robust median plate and to the central wing basivenalia, or via $1 \mathrm{Ax}$ and a proximally enlarged jutting subcostal basivenale articulated only to basivenalia, while the axillary sclerites $2 \mathrm{Ax}$ and median plate are membranized. All of the above consistently summarizes to Neoptera $=($ Pleconeoptera + Orthoneoptera $)+($ Blattoneoptera $+($ Hemineoptera + Endoneoptera)) (for examples see Haas \& Kukalová-Peck, 2001, and Kukalová-Peck \& Lawrence, 2004).

\section{CONCLUSION}

We found that the interpretation of $\uparrow$ Adiphlebia as "a beetle" by Béthoux (2009) was based on clay artefacts attached to the openings in the wing membrane. It was not supported by any other features defining Permian $†$ Protocoleoptera, modern Coleoptera, or Coleopterida 
(Coleoptera + Strepsiptera), such as the shortened mesothorax, the strongly enlarged metathorax, and posteromotorism. Suggesting any far-reaching taxonomic shifts based on a single character and without applying analytical procedures should be generally avoided. At least the interpretation should be presented as a working hypothesis and not as an established fact, which then forms the basis of evolutionary interpretations on a larger scale.

ACKNOWLEDGEMENTS. We are grateful to the curators of the Illinois State Museum in Springfield, Illinois, USA and numerous other institutions, and to H. Piecko, Chicago, T.V. Testa, Coal City, Illinois and other individuals who have provided specimens for study. The authors are much obliged to S.B. Peck (Carleton University, Ottawa, Canada) for reviewing the manuscript and for many very useful comments. Special thanks are given to T.F. Allan (Westport, ON, Canada) and M. Bertheaux (Marmora, ON, Canada) for their help in production of colored figures. J. Prokop (Charles University, Prague, Czech Republic) kindly provided photographs of some of the specimens. Portions of this work were completed with the assistance of discovery grants from the Natural Sciences and Engineering Research Council of Canada (to JKP).

\section{REFERENCES}

BAIRD G.C. 1997: Francis Creek diagenetic events. In Shabica C.W. \& Hay A.A. (eds): Richardson's Guide to the Fossil Fauna of Mazon Creek. Northeastern Illinois University, Chicago, pp. 30-34.

BÉTHoux O. 2009: The oldest beetle identified. J. Paleontol. 83 931-937.

Béthoux O. \& Briggs E.G. 2008: How Gerarus lost its head: stem-group Orthoptera and Paraneoptera revisited. Syst. Entomol. 33: 529-547.

Béthoux O., Nel A., Galtier J., Lapeyrie J. \& Gand G. 2003: A new species of Tococladidae Carpenter 1966 from the Permian of France (Insecta: Archeorthoptera). Geobios 36: $275-283$.

Béthoux O., Beckemeyer R.J., Engel M.S. \& Hall J.D. 2010: New data on Homocladus grandis, a Permian stem-mantodean (Polyneoptera: Dictyoptera). J. Paleontol. 84: 746-753.

Beutel R.G. \& HaAs F. 2000: Phylogenetic relationships of the suborders of Coleoptera (Insecta). Cladistics 16: 103-141.

Beutel R.G., Ge S.-Q. \& Hörnschemeyer T. 2008: On the head morphology of Tetraphalerus, the phylogeny of Archostemata and the basal branching events in Coleoptera. Cladistics 24: 270-298.

Beutel R.G., Friedrich F., Hörnschemeyer T., Pohl H., Hünefeld F., Beckmann F., Meier R., Misof B., Whiting M.F. \& VILHEMSEN L. 2011: Morphological and molecular evidence converging upon a robust phylogeny of the megadiverse Holometabola. Cladistics 26: 1-15.

Carpenter F.M. 1992: Superclass Hexapoda. In Kaesler R.L. (ed.): Treatise on Invertebrate Paleontology (4). The Geological Society of America and the University of Kansas, Boulder, xxii $+655 \mathrm{pp}$.

Friedrich F. \& Beutel R.G. 2008: The thorax of Zorotypus (Hexapoda, Zoraptera) and a new nomenclature for the musculature of Neoptera. Arthr. Str. Dev. 37: 29-54.
Friedrich F., Farell B.D. \& Beutel R.G. 2009: The thoracic morphology of Archostemata and the relationships of the extant suborders of Coleoptera (Hexapoda). Cladistics 25: $1-37$.

Grimaldi D. \& Engel M.S. 2005: Evolution of the Insects. Cambridge University Press, New York, 755 pp.

HaAs F. \& KuKalová-Peck J. 2001: Dermaptera hindwing structure and folding: new evidence for familial, ordinal and superordinal relationships within Neoptera (Insecta). Eur. J. Entomol. 98: 445-509.

Kukalová J. 1965: Permian Protelytroptera, Coleoptera and Protorthoptera of Moravia. Sborn. Geolog. Ved (P) 6: 61-98.

Kukaloví J. 1969: On the systematic position of the supposed Permian beetles Tshekardocoleidae with a description of a new collection from Moravia. Sborn. Geolog. Ved $(P)$ 11: 139-162.

Kukalová-Peck J. 1991: Fossil history and the evolution of hexapod structures In C.S.I.R.O. (ed.): Insects of Australia. A Textbook for Students and Research Workers. Vol. 1. 2nd ed. Melbourne University Press, Carlton, pp. 141-179.

KukalovÁ-Peck J. 1997: Arthropod phylogeny and "basal" morphological structures. In Fortey R.A. \& Thomas R.H. (eds): Arthropod Relationships. Chapman \& Hall, London, pp. 249-268.

KuKAlovÁ-Peck J. 2008: Phylogeny of higher taxa in Insecta: finding synapomorphies in the extinct fauna and separating them from homoplasies. Evol. Biol. 35: 4-51.

KukalovÁ-Peck J. 2009: Carboniferous protodonatoid dragonfly nymphs and the synapomorphies of Odonatoptera and Ephemeroptera (Insecta: Palaeoptera). Palaeodiversity 2: 169-198.

Kukalová-Peck J. \& Lawrence J.F. 1993: Evolution of the hind wing in Coleoptera. Can. Entomol. 125: 181-258.

Kukalová-Peck J. \& Lawrence J.F. 2004: Relationship among coleopteran suborders and major endoneopteran lineages: Evidence from hind wing characters. Eur. J. Entomol. 101: 95-144.

Kukalová-Peck J. \& Willmann R. 1990: Lower Permian "mecopteroid-like" insects from central Europe (Insecta, Endopterygota). Can. J. Earth Sci. 27: 459-468.

Kukalová-Peck J., Peters J.G. \& Soldán T. 2009: Homologization of the articular plate in the wing base of Ephemeroptera and Odonatoptera. In Staniczek A.H. (ed.): International Perspectives in Mayfly and Stonefly Research. Proceedings of the $12^{\text {th }}$ International Conference on Ephemeroptera and the $16^{\text {th }}$ International Symposium on Plecoptera, Stuttgart, 2008. Aquat. Insects 31 (Suppl. 1): 459-470.

Manton S.M. 1977: The Arthropoda. Habits, Functional Morphology and Evolution. Clarendon Press, Oxford, $550 \mathrm{pp}$.

Ponomarenko A.G. 1969: [Historical development of the Coleoptera - Archostemata]. Tr. Paleontol. Inst. Akad. Nauk SSSR 125: $1-240$ [in Russian].

Shear W.A. \& Kukalová-Peck J. 1990: The ecology of Paleozoic terrestrial arthropods: The fossil evidence. Can. J. Zool. 68: $1807-1934$.

Wiegmann B.M., Trautwein M.D., Kim J.-W., Cassel B.K., Bertone M.A., Winterton S.L. \& Yeates D.K. 2009: Singlecopy nuclear genes resolve the phylogeny of the holometabolous insects. BMC Biolol. 7: 34.

Received February 29, 2012; revised and accepted May 10, 2012 